\title{
Using the Mistake Buster Technique to Improve the English Grammar Mastery
}

\author{
Andi Tenrisanna Syam \\ State Islamic Institute of Palopo (IAIN Palopo), Indonesia \\ e-mail: risannasyam23@gmail.com
}

\begin{abstract}
:
This research aims at finding out whether or not the use of mistake buster technique is able to improve the English grammar mastery and finding out the students' interest toward the use of mistake buster technique. The research employs a quasiexperimental research method. The population and sample consist of 62 students which belong to two groups; 31 students in experimental group and 31 students in control group. The research data are collected using grammar test and questionnaire which are analyzed by inferential and descriptive statistics through SPSS 17.0 and Likert Scale. The research result indicates that the use of mistake buster technique is more effective than non-mistake buster technique in improving English grammar mastery of the ten grade students of SMA Negeri 3 Makassar. The students' result of posttest for experimental group is higher than the students' result of posttest for control group. It is proven by the mean score of posttest of experimental group is higher than the control group in grammar test (63.87 > 40.00). The difference of those mean score is statistically significant; it is based on t-test value at significant level 0.05, the probability value is lower than significant level $(0.00<0.05)$. Then, analysis using Likert Scale shows that the students' interested to learn grammar by using mistake buster technique. It is proved by $60.6 \%$ students were in very interested category.
\end{abstract}

Keywords: grammar mastery, mistake buster technique, students' interest 


\section{Introduction}

Mastering grammar is an important part in language learning. If we do not have good knowledge of grammar, we will surely make a lot of mistakes in speaking or in writing. The knowledge of grammar for foreign students is the basic framework to build sentences to communicate in English, so the students who do not know how to construct sentences cannot communicate well. Harmer, (2001: 22) says that knowledge of grammar is essential for competent users of language. Without some understandings of grammar, the students would not be able to do anything more than uttering separate items of language for separate functions. The expression of functional language is possible through the use of the grammar of the language. People who learn languages encounter a number of problems, especially with the grammar of the language which can be complicated.

On the contrary, in language learning, native speakers and non-native speakers are different. When the native speakers study grammar, they usually become involved not in basic framework that they know, but in problems of variant usage like dialect differences of styles and artistic effects. In contrast with this, a non-native speaker who is learning a foreign language does not know how its structure. He needs to acquire this basic framework in order to master the production and the comprehension of the typical sentences of the language. Yet, he and those people who teach him often forget this fact and proceed with teaching and learning the foreign language as if it were the native language; he takes up matters of variant usage, looks sight of the central structure, and ignores its importance and difficulties.

As non-native speakers, Indonesian students have difficulties in learning English grammar. Specifically, based on the researcher's interview with the teacher of SMA Negeri 3 Makassar, the students' grammar mastery at SMA Negeri 3 Makassar is generally still low. One of the indicators is many wrong answers of students' when they are given grammar tests. This problem comes to surface because of some cases. Among of them is students do not have background knowledge about the lesson given, teachers just explain grammar to students directly followed by answering the questions without having discussion first and providing visual aid to students. In addition, students do not know when such grammar should be used in and how their application in daily life.

Fromkin (2007) emphasizes the important role of teaching grammar is to fulfill the language requirements. Teaching grammar states explicitly the rules of language, list the words and their pronunciations and aid in learning a new language. Therefore, the teacher should teach grammar entirely because grammar is essential part of language.

Therefore, to make the English teaching in Indonesia successful, it is necessary to create new penetration and new strategies in order to support and improve the quality of the education well. Besides, English teachers should straighten and fix themselves by enriching themselves with methods and knowledge which relate to their profession as English teachers. And also it is necessary to take enterprise in 
order to create new techniques and methods in teaching and learning activities, especially in the classroom activity. English teachers must enrich themselves by using various methods and media to motivate and give enthusiasm to students in learning English. English teachers should create enjoyable, relaxed, and comfortable atmosphere in the classroom. Nowadays, there are many ways to view the grammar of the language and many ways to teach it. However, these are essential problems that must be concerned by the English teachers, which will influence the way they approach grammar in the classroom i.e. many students may find difficult on grammatical concepts and most of the English teachers have not used specific techniques in teaching grammar.

The technique can be applied in teaching grammar is the mistake buster technique. Some researchers observed the use of mistake buster technique and figured out some useful of it. The mistake buster technique is a simple technique which is simply to help students learn better by creating good opportunities for them to reflect on what they have learned and now take a look at it from a different angle (Huynh, 2003), it can be used in facilitating students' grammar mastery (Hanifa and Tiarina, 2013; Maezida, 2013), and it helps the English teachers to check student's understanding about grammatical rules and improving writing and production skills (Amtiran, et al., 2016).

\section{Literature Review}

Grammar is a field of linguistics that involves all the various things that make up the rules of language. According to Joyce and Burns, (2001: 2) grammar is the study and practice of the rules by which words change their forms and they are combined into sentences. Simon and Schuster, (in Rusdy, 2010: 16) define grammar as the part of the study of language which deals with the forms and structure of words (morphology) and with their customary arrangement in phrases and sentences (syntax), formerly used to denote all phrases of language study (except that of the detailed meaning of words), as centred on morphology and syntax, and now often distinguished from the study of pronunciation (phonology) and that of word meanings (semantics). It can be said that a grammar is the system of word structures and word arrangements of a given language at a given time.

Technique is implementational that actually takes place in a classroom. It is a particular trick, stratagem, or contrivance used to accomplish an immediate objective. According to Brown, (2001) technique is any wide variety of exercises, activities, or devices used in the language classroom for realizing lesson objectives. One of the techniques can be used in teaching English is mistake buster technique. It is an activity where the students take over the role of correcting mistakes (which is normally done by the teacher), while I deliberately become the "mistake maker" (Huynh, 2003).

\section{Research Methodology}

This research used a quasi-experimental method which compared two groups which were treated using mistake buster technique and non-mistake buster technique. Both groups were given pretest and posttest. The population of this research was the ten 
grade students of SMA Negeri 3 Makassar. The total number of classes was two classes. Each class consisted of 31 students. The total number of the students was 62. The sample was taken based on cluster sampling technique. This research employed single instrument based on the variables investigated; it was grammar achievement test. The test consisted of two kinds of test: pretest and posttest. The instrument was intended to measure the students' achievement of language element particularly grammar. The forms of the test were multiple choices with fouralternative and fill in the blank. The total numbers of the questions were 30 items. The questionnaire was conducted to get the data of the students' interest toward the use of mistake buster technique in teaching grammar. There were 20 items; 10 items of positive statement and 10 items of negative statement. The questionnaire was distributed to the students after giving the posttest and it was analyzed by suing Likert Scale. The researcher gave the treatment to the students of experimental and control groups. It was done for six meetings for each group. The experimental group was taught by using mistake buster technique while the control group was taught with non-mistake buster technique.

\section{Findings}

\subsection{Scoring Classification}

\subsubsection{Scoring Classification of the Students' Pretest and Posttest in Control Group}

Students' score of pretest were classified into some classification. The result of pretest of control group is none or $0 \%$ of students got "excellent," "good," "fairly good," and "fair", scores and all of students or $100 \%$ got "poor" score. In line with the pretest percentage and frequency, the result of posttest, 21 or $67.7 \%$ students got "poor" score, 7 or $22.6 \%$ students got "fair" score, 3 or $9.7 \%$ students got "fairly good" score, none of them got "good" and "excellent" scores.

\subsubsection{Scoring Classification of the Students' Pretest and Posttest in Experimental Group}

Students' score of pretest were classified into some classification. The result of pretest of experimental group is none or $0 \%$ of students got "excellent," "good," and "fairly good" scores, and 2 or $6.5 \%$ of students got "fair" and 29 or $93.5 \%$ students got "poor" scores. While the result of posttest, 6 or 9.4\% students got "poor" score, 10 or $32.3 \%$ students got "fairly good" score, 13 or $41.9 \%$ students got "good" score, and 1 or $3.2 \%$ student got "fair" score and only 1 or $3.2 \%$ student got "excellent" score. The comparison between pretest and posttest result shown that there was significant improvement in posttest result in experimental group.

\subsection{The Students' Scores of Pretest and Posttest in Control Group}

The researcher presents the difference of the students' vocabulary achievement before treatment and after treatment (pretest and posttest) in control group. The control group was not treated as experimental group but another way. The mean score of students' pretest in control group was 31.61 and the standard deviation was 5.49 , while in posttest the mean score was 40.00 and the standard deviation was 10.46. It meant that the ability of the students in control group either of pretest or 
posttest statistically had the same level. Gay (2006:124) states that the difference between close score is essentially the same to the students mean score between pretest and posttest was relatively the same when the variables have equal intervals. Both pretest and posttest had the same or relatively the same baseline knowledge in grammar achievement before and after the treatment.

\subsection{The Students' Scores of Pretest and Posttest in Experimental Group}

The researcher presents the difference of the students' grammar achievement before treatment and after treatment (pretest and posttest) in experimental group. The experimental group was treated by activating and encouraging or enriching movie in order the students had improvement in their grammar achievement. The mean score of students' pretest in experimental group was 33.06 and the standard deviation was 7.54 , while in posttest the mean score was 63.87 and the standard deviation was 13.09. It means that the grammar achievement of the students in experimental group was different before and after the treatment. It is concluded that the students had an improvement in their vocabulary achievement after they were given the treatment.

\subsection{The Comparison between the Students' Scores of Pretest and Posttest in Control and Experimental Group}

The mean score of students' pretest of experimental group was 33.06 and control group was 31.61. It is concluded that the students mean score of experimental group was statistically the same with control group. Gay (2006:124) states that the difference between close score is essentially the same to the students mean score between experimental and control group was relatively the same when the variables have equal intervals. Both experimental and control group had the same or relatively the same baseline knowledge in grammar achievement before the treatment.

To the following, the researcher presents the difference of the students' grammar achievement after giving treatment to both experimental and control group. The experimental group was taught by using movie while control group was not. Further explanation for students' achievement on the posttest score after the treatment was done in order to find the significant difference, the researcher applied t-test formula to analyze whether or not it is significant. In this case, the posttest score was analyzed at the significant level 0.05 or $\alpha$ equals to 0.05 by using inferential statistic through SPSS program version 17.0.

The mean scores of both experimental and control group were different after treatments. The mean score of experimental group was $63.87(33.06<63.87)$ whereas the control group was $31.61(31.61<40.00)$. The mean score of experimental group is higher than control group $(63.87>40.00)$ and the standard deviation for experimental group was 13.09 and control group was 10.46. It showed that after giving the treatment, the result of experimental group on the mean score was higher than the control group. It proved that the treatment with movie gave improvement to students' grammar achievement 


\subsection{The Calculation of Pretest of t-test in Experimental Group and Control Group}

The following shows the achievement of the students' pretest and posttest in experimental group before and after giving treatment, the result of t-test was calculated using inferential statistic through SPSS program version 17.0. The following also meant testing hypotheses.

Table 1. The t-test of the Students' Pretest in Experimental Group and Control Group

\begin{tabular}{ccc}
\hline Variable & $(\alpha)$ & Probability Value \\
\hline Pretest & 0.05 & 0.391 \\
\hline
\end{tabular}

Based on statistics test shown in Table 1 above, it is concluded that the Probability value is lower than alpha $(\alpha)(0.391<0.05)$. It means that $\mathrm{H}_{1}$ was rejected and $\mathrm{H}_{0}$ was accepted. It is concluded that there is no significant difference before treatment in pretest and after treatment in posttest.

\subsection{The Calculation of t-test Posttest for Experimental Group and Control Group}

The data shown below indicated the achievement of experimental and control groups after conducting the treatment, the result of t-test was calculated using inferential statistic through SPSS program version 17.0. The following also meant testing hypothesis.

Table 2. The t-test of the Students' Posttest in Experimental Group and Control Group

\begin{tabular}{ccc}
\hline Variable & $(\alpha)$ & Probability Value \\
\hline Posttest & 0.05 & 0.000
\end{tabular}

Table 2 above showed that the Probability Value is lower than alpha $(\alpha)(0.000<$ $0.05)$. It means that $\mathrm{H}_{1}$ was accepted and $\mathrm{H}_{0}$ was rejected. It is concluded that there was a significant difference after treatment in control group and after treatment in experimental group. It indicated that mistake buster technique is able to give greater contribution on the students' grammar achievement. It could be stated that using the mistake buster technique improves the students' grammar achievement.

\subsection{Scoring Classification of Students' Interest}

Students' score of interest were classified into some classification. The frequency and the rate percentage of the students' score of interest are presented as follows: 


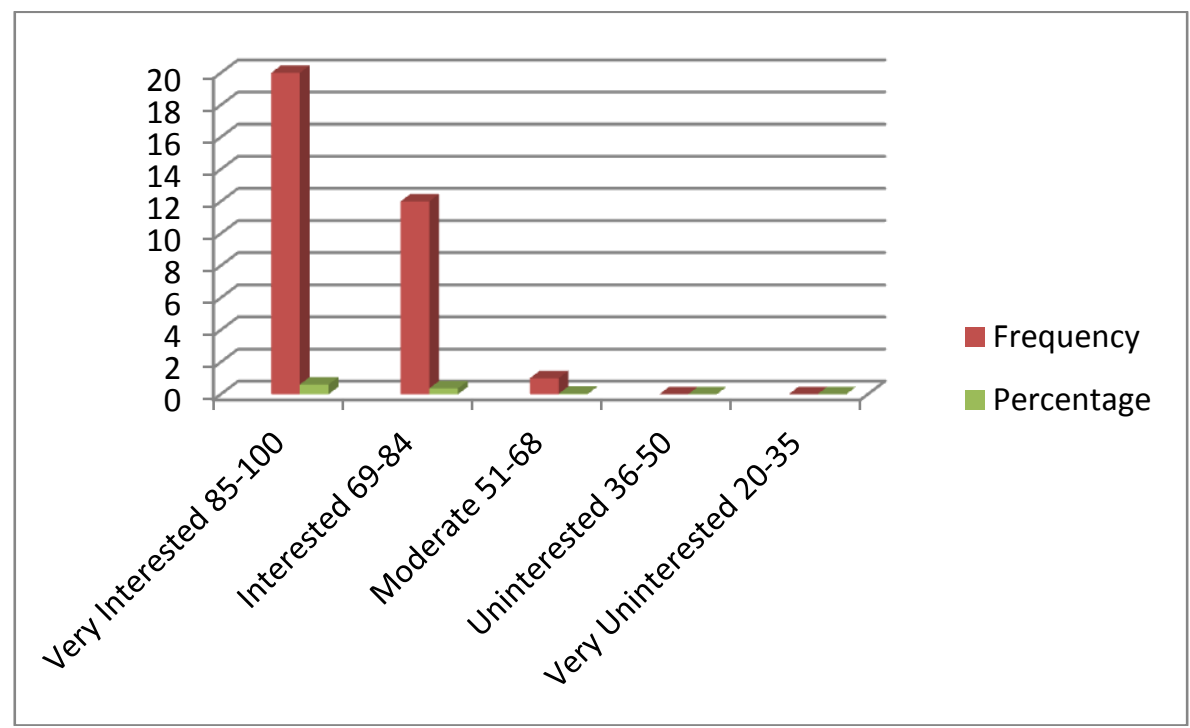

Figure 1. The Students' Interest Classification

The data showed that 20 students or $60.6 \%$ were in very interested category, 1 student or $3 \%$ was in moderate category, and only 12 students or $36.4 \%$ were in interested category. It means that movie was effective to raise students' interest in learning grammar.

Table 3 The Mean Score of Students' Interest

\begin{tabular}{ccc}
\hline $\begin{array}{c}\text { Total } \\
\text { Respondent }\end{array}$ & Mean Score & Total of students' score \\
\hline 33 & 85.93 & 2836 \\
\hline
\end{tabular}

Table 3 shows that the mean score of the students' interest is 85.93 which is meant it is in very interested category according to the range of students' interest score.

\section{Discussion}

This section deals with argument and further interpretation of the research findings in grammar achievement both pretest and posttest results of experimental and control group.

Based on the students' work in the pretest of both experimental and control group, the researcher analyzed that most students had low achievement in grammar. In control group, the mean score of posttest was also higher than the mean score of pretest $(40.00>31.61)$ but the difference was not statistically significant because probability value was higher than alpha $(.156>0.05)$. On the contrary, in experimental group, based on the description of the data collected through test as explained in the previous section shows that the students' achievement in grammar increases significantly. It was supported by the mean score rate of result of the 
students' pre-test and post-test of experimental group. The mean score of pre-test and post-test of experimental group were 33.06 and 63.87 and the standard deviations were 7.54 and 13.09 .

In analyzing the students' achievement in both groups, besides comparing the students' result in pretest and posttest of each group, the researcher also compared the students' result combining the group. The researcher compared the students' result of pretest in control and experimental group and compared the students' result of posttest in control and experimental group. The result shows that the ability of the students in pretest both control and experimental group were in the mean score 31.61 and 33.06. This means that in the pretest both control and experimental group had an equal ability, because the score was still around on 60.00 points. On the contrary, in the posttest of both control and experimental group, the students' mean score were 40.00 and 63.87 . This means the ability of the students both group was different after given treatments. It is concluded that using the mistake buster technique improves the students' grammar achievement using conventional way applied in control group.

Based on the students' result obtained and stated in findings and discussion above, the researcher used t-test in inferential statistic through SPSS version 17.0 program to test the hypothesis. Based on statistics test, it is concluded that the Probability Value is lower than alpha $(\alpha)(0.000<0.05)$. It means that $\mathrm{H} 1$ was accepted and $\mathrm{H} 0$ was rejected. It is concluded that there was a significant difference before treatment in pretest and after treatment in posttest. In other words, there was an improvement on the students' grammar achievement between posttest in both experimental and control group after the treatment. Then, it is concluded that the mistake buster technique is able to give greater contribution to the students' grammar achievement.

The data showed that 20 students or $60.6 \%$ were in very interested category, 1 student or $3 \%$ was in moderate category, and only 12 students or $36.4 \%$ were in interested category. It means that students were strongly interested in learning grammar by using the mistake buster technique.

The findings of this research were the same with previous studies. Most of researchers found that mistake buster technique is effective to be applied in teaching grammar and writing. Maezida (2013) the result of her study showed the improvement of students' scores who taught by mistake buster technique. Nisa (2016) found that students' understanding on writing recount text after getting treatment had higher achievement than in control class.

The teaching of grammar must help the students understand grammar well. One of the techniques that can be used is mistake buster technique. Of course, combining the technique with the use of technology is also powerful in the teaching of grammar. Jalali and Dousti (2012) claimed that the involvement of all learners, their enthusiasm to use the new technology in language learning and learners' positive attitudes toward learning was apparent in the teaching and learning process. Thus, the use of ICT is very helpful in English teaching and learning process (Laabidi and Laabidi, 2016a; Laabidi and Laabidi, 2016b; Chouit, et al., 2017). 
The successful teaching is depend on the teacher, since the English teacher has a great role to play in enhancing the language proficiency of a learner (Küçükler, 2016). The English teachers must develop the knowledge and skills they need to address students' learning challenges, so that it enables the teacher to address gaps in teaching/learning and fill them (Benzehaf, 2016).

\section{Conclusion}

The use of mistake buster technique significantly improves the students' grammar achievement. The mean score of students' pretest in both groups are relatively the same. While in posttest the mean score was significantly different where the mean score of experimental group was higher than control group $(63.87>40.00)$. The result of hypothesis testing showed that the difference of mean score above was significant $(0.00<0.05)$. It means that the use of movie is effective in improving the vocabulary achievement of the ten grade students of SMA Negeri 3 Makassar.

The questionnaire was given after the posttest to know the students' interest in using the mistake buster technique. Based on the analysis of questionnaire the researcher concluded that the students were very interested in the use of mistake buster technique.

\section{References}

Amtiran, Santi Yuliana., I Ketut Artawa., Anak Agung Putra. (2016) Pemakaian Teknik Mistake Buster dalam Pembelajaran Verba Past Tense pada Siswa Kelas X AP 1 di SMK Pariwisata Triatma Jaya Badung. Journal of Language and Translation Studies. Volume 2 No 3, (1-14).

Azar, Betty Schrampfer. (1992). Fundamentals of English Grammar. (Second Edition). New Jersey: Regents/Prentice Hall.

Bariun. (2003). A Correlative Study of Second Year Students' Mastery of English Vocabulary and Structure with their Achievement at SLTP in Kota Bau-Bau. Unpublished thesis. Makassar: PPs UNM.

Benzehaf, Bouchaib. (2016). Expanding Teacher Comfort Zones: Developing Professionalism. JELTL (Journal of English Language Teaching and Linguistics), 1(3), 2016

Bowen, C. P. (1999). "Technology Helps Students Learn Grammar." Communication: Journalism Education Today, 32(4), 17-18.

Brown, H. Douglas. (2001). Teaching by Principles: an Active Approach to Language Pedagogy. London. Longman Group UK Limited.

Burden, Paul R and David M. Byrd. (1999). Effective Teaching. (Second Edition). Manhattan: Kansas State University. .

Chouit, D., Nfissi, A., Laabidi, H. (2017). Exploring the Correlation between Professors' Use of ICT in Teaching and the Levels of Institutional Support. JELTL (Journal of English Language Teaching and Linguistics), 2(1), 2017. doi: http://dx.doi.org/10.21462/jeltl.v2i1.39

Danim, Sudarwan. (1995). Media Komunikasi Pendidikan. Jakarta: Bumi Aksara. Fromkin. (2007). an Introduction to Language. Boston: Thomson Wadsworth. 
Hanifa, Gemala Imelda and Tiarina, Yuli. (2013). Using the Mistake Buster Technique in Teaching Grammar to Junior High School Students. Journal of English Language Teaching, Vol. 1 No. 2, Maret 2013

Harmer, Jeremy. (2001). the Practice of English Language Teaching. London: Longman Group UK Limited.

Haryanto. (2008). Grammar Exercises for Academic Purposes. Makassar: State University of Makassar.

Henning, G. (1987). A Guide to Language Testing: Development, Evaluation, Research. Boston: Heinle \& Heinle Publishers.

Huynh, Hay K. P. (2003). Getting students actively involved using the mistake buster technique. Retrieved from http: //www.itelsj.org/Techniques/HuynhMistake Buster.html.

Jalali, Sara and Dousti, Masoumeh. (2012). Vocabulary and Grammar Gain Through Computer Educational Games. GEMA Online ${ }^{\circledR}$ Journal of Language Studies . Vol 12, No 4 (2012)

Joyce, Helen de Silva and Anne Burns. (2001). Focus on Grammar. Sydney: Southwood Press.

Küçükler, Halil. (2016). Autonomous Learning for Proficiency Level in Foreign Language Development of Graduate Students. Indonesian Journal of EFL and Linguistics, 1(2), 2016

Laabidi, Hicham \& Laabidi, Youssouf. (2016a). A Quantitative Examination of Factors that Influence Technology Integration in Higher Education System. Indonesian Journal of EFL and Linguistics, 1(2), 2016

Laabidi, Youssouf \& Laabidi, Hicham. (2016b). Barriers Affecting Successful Integration of ICT in Moroccan Universities. JELTL (Journal of English Language Teaching and Linguistics), 1(3), 2016

Lin, Caroline Ho Mei. (1997). Teacher's Tips: (Online). Grammar Teaching and Learning. Singapore News Magazines 'Society for Reading and Literacy', 3rd quarter Vol. 9 No. 3, p.11-12.

Maezida, Azizatin Nida. (2013). The Simple Past Tense Mastery of the Eighth Grade Students of MTs NU Muallimat Kudus in the Academic Year 2012/2013 Taught by Using Mistake Buster Technique. Thesis. Kudus: University of Muria Kudus.

Nisa, Mifrohatun. (2016). The Effectiveness of Using Mistake Buster Technique in Teaching Writing on Recount Text (An Experimental Study at Eighth Grade of SMP Islam Asy-Syafi'iyah Batealit Jepara in the Academic Year of 2016/ 2017. Semarang: Walisongo State Islamic University. 